\title{
Narratiivinen \\ positiointianalyysi ja \\ nuorten aikuisten toimijuus \\ työpajaympäristössä
}

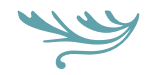

Työpajoissa toimivia nuoria aikuisia ympäröi huoli syrjäytymisestä ja osallistumisesta koulutukseen ja työhön.

Narratiivinen positiointianalyysi nuorten kertomuksista

osoittaa, että he ovat myös aktiivisia toimijoita ja identiteettinsä rakentajia.

У

TARKASTELEMME TÄSSÄ ARTIKKELISSA Michael Bambergin ja hänen kollegoidensa (Bamberg 1997, 2004a, 2004b; Bamberg \& Georgakopoulou 2008; De Fina 2013) kehittämää narratiivista positiointianalyysia nuorten aikuisten koulutusvalinnoista, koulutuksesta ja työpajakokemuksista kertomien pienten kertomusten (small story) analyysissa. Bamberg ja Georgakopoulou (2008) liittävät pienen kertomuksen käsitteen luonnollisiin arkipäivän puhetilanteisiin, mutta tässä artikkelissa ymmärrämme pienen kertomuksen haastattelupuheen sisällä oleviksi lyhyiksi puhejaksoiksi. Tarkastelumme pohjautuu Heli Mutasen meneillään olevaan väitöskirjatutkimukseen ja tutkimusta varten työpajassa tuotettuun nuorten aikuisten haastatteluaineistoon sekä tutkimuspäiväkirjoihin.

Työpajalla viittaamme työttömille alle 25 -vuotiaille nuorille ja alle 30-vuotiaille vastavalmistuneille nuorille aikuisille tarkoitettuun yhteisöön, jossa työskentelyllä ja siihen liittyvillä ohjaus- ja valmennuspalveluilla pyritään tukemaan nuorten elämäntaitoja, omatahtista kasvua ja koulutus- tai työuran löytymistä (Opetus- ja kulttuuriministeriö 2006). Tutkimuksessa olevassa työpajassa painottui aineiston hankkimisen ajankohtana erityisesti nuorten aikuisten ohjaaminen koulutus- tai työurille. 
Pohdimme artikkelissa, millaisia mahdollisuuksia narratiivinen positiointianalyysi tarjoaa erityisesti marginaaliin asetettujen nuorten aikuisten toimijuuden ja identiteetin tutkimukseen. Lisäksi tarkastelemme, kuinka sen avulla voidaan analysoida identiteetin ja toimijuuden rakentumista suhteessa kulttuurisiin mallitarinoihin. Kulttuuriset mallitarinat ymmärrämme yhteiskunnassa laajasti hyväksytyiksi uskomuksiksi sekä ennakkokäsityksiksi ympäröivästä todellisuudesta ja malleiksi siitä, kuinka yksilöiden tulisi kulttuurissa tavanomaisesti toimia (Hänninen 1999, 50). Tällaisia kulttuurisia mallitarinoita ovat esimerkiksi työpajassa toimiville nuorille aikuisille tarjolla olevat tarinat, jotka kertovat koulutuksen sujuvasta läpäisystä ja nopeasta siirtymästä työelämään.

Pienten kertomusten analyysiä korostavassa lähestymistavassa kerronta nähdään sosiaalisena konventiona ja toimintana vastakohtana elämäkerralliselle isojen kertomusten (big story) tutkimukselle, joka korostaa yksilön minuuden autenttisuutta sekä kertomusta ihmisen identiteetin peilinä (ks. Andrews, Day Sclater \& Treacher 2004; Hyvärinen 2006; Bamberg \& Georgakopoulou 2008). Työpajakontekstissa nuoret aikuiset tuottivat pääasiassa tällaisia pieniä, paikoitellen epäjohdonmukaisia kertomuksia ja lyhyitä kuvauksia menneistä ja nykyisistä tapahtumista sekä tulevaisuuden mahdollisista tapahtumista (ks. Bamberg \& Georgakopoulou 2008, 381; Hyvärinen, Hydén, Saarenheimo \& Tamboukou 2010, 11). Määrittelemme lisäksi pienen kertomuksen Georgakopouloun ja Goutsos'in (2002) tapaan kerronnaksi, jossa kuvataan asiantilan jonkinlainen muutos ja kertojan esittämä moraalinen arvio siitä. Moraalinen arvio yhdistää kokemuksen ja kerronnan.

Keskiluokkaista koherenttia identiteettikertomusta korostava elämäkerrallinen lähestymistapa ei olisi antanut arvoa eikä tehnyt oikeutta työpajakontekstissa toimivien nuorten aikuisten kokemuksille ja kertomuksille (vrt. Hyvärinen ym. 2010, 10-11). Vastakkainasettelu isojen ja pienten kertomusten välillä on kuitenkin siinä mielessä keinotekoinen, että teoreettiset ja metodologiset lähtökohdat rakentavat ymmärrystä siitä, miten kertomus - iso sekä pieni kulloinkin määritellään ja miten sitä analysoidaan
(Helsig 2010). Vaikka kutsumme työpajojen nuorten aikuisten kertomuksia pieniksi, myös he rakentavat kerronnallaan toimijuuttaan ja ymmärrystään itsestään siinä sosiaalisessa ympäristössä, jossa he ovat osallisina.

Analysoimalla aineiston pieniä kertomuksia narratiivisen positiointianalyysin avulla pyrimme selvittämään, millaisia identiteettipositioita työpajan nuoret aikuiset rakentavat tarinan ja kerronnan tasolla sekä suhteessa kulttuurisiin mallitarinoihin (Bamberg 1997, 2004a, 2004b). Analyysimme lähtökohtana on, että työpajassa toimivat nuoret eivät vain asetu tai alistu ennakkoon määriteltyihin kulttuuristen mallitarinoiden tarjoamiin identiteettipositioihin. Sen sijaan he ovat aktiivisia toimijoita ja kertomuksen tuottajia sekä neuvottelevat erilaisista mahdollisista identiteettipositioista tilanteisesti. (Ks. myös Bamberg 2004a, 153.)

Ymmärrämme kertomukset sosiaalisesti, historiallisesti ja paikallisesti rakentuneiksi, emme tapahtumien ja kokemusten suoriksi representaatioiksi (esim. Atkinson \& Delamont 2006). Narratiivisen positiointianalyysin tavoitteena on tarkastella ja tulkita kertomuksia sosiaalisena toimintana siinä kulttuurisessa kontekstissa, jossa ne kerrotaan. Ymmärrämme kontekstin Jaber F. Gubriumin ja James A. Holsteinin $(2008,247)$ tavoin kerronnalliseksi ympäristöksi. Se koostuu sekä haastattelun vuorovaikutustilanteesta että haastattelua ja kerrontaa ympäröivästä sosiaalisesta ympäristöstä ja siinä tarjolla olevista kulttuurisista mallitarinoista (mt.).

Työpajoissa olevia nuoria aikuisia ympäröi yhteiskunnallinen huoli- ja syrjäytymispuhe sekä yksilön koulutukseen ja työelämään osallistumisesta kertovat kulttuuriset mallitarinat. Näin ollen myös analyysissa on siirryttävä tarkastelemaan tarinoita ja kerrontaa tilanteisina neuvotteluina, jolloin kerronnallinen ympäristö muokkaa sitä, mitä kerrotaan ja kuinka kerrotaan (Gubrium \& Holstein 2008, 247).

Taustoitamme seuraavaksi narratiivisen positiointianalyysin teoreettisia lähtökohtia sekä sitä, miten narratiivista positiointianalyysia on tässä artikkelissa käytetty. Tämän jälkeen kuvaamme työpajassa tuotetun aineiston ja tutkimuksen kerronnallisen ympäristön. Konkretisoimme analyysiä aineisto- 
esimerkin avulla. Lopuksi pohdimme menetelmän mahdollisuuksia aikuiskasvatustieteellisessä tutkimuksessa.

\section{POSITIOINTITEORIA JA NARRATIIVINEN POSITIOINTI - TEOREETTISET LÄHTÖKOHDAT}

Narratiivisen positiointianalyysin taustalla oleva positiointiteoria (Davies \& Harré 1990; Harré \& Langenhove 1999) on kehitetty teoreettiseksi malliksi selittämään sosiaalista toimintaa ja merkitysten rakentumista henkilöiden välisessä vuorovaikutuksessa ja diskursiivisissa käytännöissä. Positioilla viitataan puhetilanteissa tuotettuihin diskursiivisiin tiloihin ja suhteissa muovautuviin paikkoihin. Ne sisältävät erilaisia henkilöön liittyviä persoonallisia määrittelyjä ja positioon liittyviä moraalisia oikeuksia ja velvollisuuksia.

Keskustelun kulku muodostaa vuorovaikutuksessa juonen tai tarinalinjan (storyline). Siinä osallistujien positiot rakentuvat heidän hyväksyessään, vastustaessaan tai muokatessaan tarjoutuvia positioita. Näin ollen henkilöt ovat vuorovaikutustilanteissa sekä yhteisten tarinalinjojen tuottajia että niiden tuottamia. Kerronnan käytännöt rakentavat puhetilanteessa tarjolla olevia tarinalinjoja. Positiointi mahdollistaa hienovaraisen lähiluvun toimijuuden ja identiteetin rakentumisen tarkasteluun kontekstuaalisena ja tilanteisena ilmiönä (Davies \& Harré 1990; Benwell \& Stokoe 2006). Käytämme artikkelissa rinnakkain sekä positioinnin että asemoinnin käsitteitä (ks. Pöysä 2009).

Michael Bamberg (1997, 2004a, 2004b) ja myöhemmin Bamberg ja Georgakopoulou (2008) ovat tuoneet positioinnin käsitteen narratiivisen tutkimuksen genreen, jossa kerronnallisuus ymmärretään keskeisenä identiteetin rakentumisessa. Narratiivisessa positiointianalyysissä identiteetti nähdään sosiaalisessa vuorovaikutuksessa rakentuvana, jolloin yksilöt muodostavat ja muokkaavat ymmärrystä itsestään tilanteisesti. Tässä mielessä kertomukset eivät ole vain keino reflektoida menneitä tapahtumia. Niillä myös tuotetaan, omaksutaan tai vastustetaan sekä kerronnan tilanteessa tarjoutuvia positioita että kulttuurisissa mallitarinoissa tarjoutuvia positioita. Samalla neuvotellaan niin paikallisista identiteeteistä kuin laajemmista sosiaalisista identiteeteistäkin. (Bamberg \& Georgakopoulou 2008, 378-379.)

Narratiivisessa positioinnissa identiteetin rakentumista tarkastellaan sekä tarinan että kerronnan vuorovaikutustilanteen tasolla. Positioista neuvotellaan, niitä tuotetaan ja omaksutaan käyttämällä erilaisia puhetapoja ja hyödyntämällä erilaisia kielellisiä välineitä, kuten pronomineja ja verbejä (Bamberg 2004a, 137, 139). Identiteetit ymmärretään pikemminkin liikkeessä oleviksi ja moninaisiksi; identiteettiä rakennetaan ja siitä neuvotellaan niissä sosiaalisissa tilanteissa, joissa yksilöt ovat läsnä (Hall 1999, 22-23, 29).

Narratiivisessa positiointiteoriassa toimijuus nähdään identiteettien työstämisen keskeisenä elementtinä (Bamberg 2004a, 2004b; ks. myös Eteläpelto, Vähäsantanen, Hökkä \& Paloniemi 2014). Bamberg (2004a, 136-137) jäsentää toimijuutta kahdella metaforisella käsitteellä: positioitu (asemoitu, being positioned) ja positioida (asemoida, positioning itself). Positioitu viittaa deterministiseen käsitykseen toimijuudesta. Tällöin positiot määrittyvät diskursseissa ja toimijuus kutistuu valinnaksi tarjolla olevien positioiden välillä.

Bamberg (2004a, 153) kuitenkin olettaa, että subjektit eivät vain toteuta ennakkoon määriteltyjä minuuksia ja identiteettejä tai alistu kulttuurisissa mallitarinoissa tarjolla oleviin identiteetteihin. Hän korostaa yksilön aktiivista toimijuutta (positioning self) kertomuksen tuottajana ja rakentajana ja erilaisten mahdollisten positioiden tilanteisena neuvottelijana.

Bamberg (2004a) tähdentää, että vaikka metaforat edustavat kahta erilaista toimijuuskäsitystä, ne kuitenkin kietoutuvat toisiinsa toimijuuden tilanteisissa neuvotteluissa. Näin ollen toimijuus voidaan ymmärtää prosessina, joka kehittyy vuorovaikutustilanteissa suhteessa toisiin ihmisiin, yhteisöihin ja instituutioihin (ks. Edwards \& Mackenzie 2005). Toimijuuden rakentumisessa ovat läsnä menneisyyden kokemukset, käsillä olevan vuorovaikutustilanteen tarjoumat (positiot, tarinalinjat) sekä tulevaisuudessa havaitut mahdollisuudet (ks. Evans 2007). Toimijuus tulisi nähdä myös ajallisesti etenevänä prosessina niissä sosiaalisissa ympäristöissä, joissa yksilö on osallisena (Emirbayer \& Mische 1998; Eteläpelto ym. 2014, 208). 


\section{NARRATIIVINEN POSITIOINTIANALYYSI}

Davies ja Harré (1990) jättävät positiointiteoriassaan varsinaisen analyysimenetelmän varsin väljäksi. Bamberg (1997, 2004a, 2004b) on kehitellyt Hollwayn (1984) ja Daviesin ja Harrén (1990) ajatteluun sekä Labovin ja Waletzkyn (1967) kertomuksen rakennemallin analyysiin pohjaavan kolmitasoisen narratiivisen positiointianalyysimallin, jossa toisiinsa kietoutuvia eri tasoja tarkastellaan analyyttisesti erillään. Narratiivisen positiointianalyysin avulla pyritään tavoittamaan toimijuutta, minuuksia ja identiteettejä. Se tapahtuu analysoimalla, millaisia positioita kertojat aktiivisina toimijoina rakentavat tarinamaailman ja kerronnan tasolla sekä suhteessa normatiivisiin valtadiskursseihin, joita kulttuuriset mallitarinat edustavat. (Bamberg 2004b, 336.)

Tarinamaailman (story world) tasolla analysoidaan, miten tarinassa mukana olevat henkilöt asemoituvat suhteessa toisiinsa ja erityisesti, miten kertoja asemoi itsensä suhteessa muihin tarinan henkilöhahmoihin. Analyysissa ollaan kiinnostuneita siitä, miten tarinan henkilöhahmot rakentuvat; kuka päähenkilöksi, kuka vastustajaksi, sivusta seurailijaksi, kohteeksi tai kärsijäksi. Analyysin konkreettisina työkaluina hyödynnetään puhunnan ja kielenkäytön tapoja, kuten kertojan näkökulmaa, aikamuotoja ja henkilöhahmoihin liittyviä määrityksiä. (Bamberg 1997, 337; 2004b, 333.)

Kerronnan (telling) tasolla analysoidaan kertojan asemoitumista suhteessa yleisöönsä ja kuulijoihinsa. Haastattelutilanteessa kerronnan analyysi tarkoittaa kertojan ja haastateltavan vuorovaikutuksen tarkastelua neuvotteluna, jossa haastattelijan kysymykset ja haastateltavan tulkinta sopivasta ja toivottavasta kertomuksesta kietoutuvat yhteen (De Fina 2009). Analyysissa pyritään paljastamaan erityisiä kielenkäytön ja puhunnan tapoja, joilla tarkoitetaan muun muassa sitä, pyrkiikö kertoja kontrolloimaan mukana olevia toisia vai ehkä puolustelemaan tekojaan syyttämällä toisia (Bamberg 1997).

Kolmannella tasolla tarkastellaan kertojan asemoitumista suhteessa vallalla oleviin mallitarinoihin: "Kuka minä olen suhteessa siihen, mitä yhteiskunta minulta odottaa?” (Watson 2007). Näin ollen kolmannen tason analyysillä pyritään linkittämään sekä mikrotason identiteettejä että makrotasolla vaikuttavia kulttuurisia ja sosiaalisia identiteettikategorioita, joita yksilöt hyödyntävät tai jättävät hyödyntämättä rakentaessaan identiteettejään (Bamberg 1997; 2004b).

Bethan Benwell ja Elizabeth Stokoe (2006, 158 159, ks. myös Deppermann 2013, 84) näkevät positiointianalyysin ongelmaksi sen, kuinka kerronnallisen ympäristön kulttuurisia mallitarinoita voi analyyttisesti lähestyä. He esittävät, että mallitarinat jäävät pitkälti tutkijan arvauksiksi siitä, mitä kertoja on mahtanut tarkoittaa ja mitä sosiaalisen maailman representaatioita hän käyttää kertomuksissaan.

Bamberg (2004a, 337; ks. myös De Fina 2013, 45-46) ehdottaa, että kulttuuriset mallitarinat tulevat näkyviksi analysoitaessa puhetta yksityiskohtaisesti positiointianalyysin kehikossa. Anna De Fina (2013, 45; myös Deppermann 2013, 84) jatkaa, että mallitarinoiden havaitsemista tukee etnografinen tutkimusote. Sillä hän tarkoittaa pitkähköä havainnointia siinä ympäristössä, jossa ilmiötä tutkitaan eli tutustumista tutkimuksen kohdejoukkoon ja perehtymistä käytössä oleviin puhetapoihin. Toiseksi, kulttuuriset mallitarinat voivat tulla näkyviksi aiemmassa tutkimuskirjallisuudessa ja esimerkiksi poliittisissa asiakirjoissa. (De Fina 2013, 54-55.) Tässä artikkelissa hyödynnetään sekä narratiivista etnografiaa (Gubrium \& Holstein 2008), tutkimuskirjallisuutta ja asiakirjoja että tarkastellaan koko aineistossa esiintyviä yhteneviä puhetapoja.

Bamberg ja Georgakopoulou (2008) ovat käyttäneet narratiivista positiointianalyysia analysoidessaan arkipäivän puhe- ja ryhmätilanteita. Narratiivista positiointianalyysia on käytetty myös haastatteluaineistoissa, vaikkakin niukalti. Lora Arduser (2014) on analysoinut diabetekseen sairastuneiden aikuisten $(n=12)$ neuvotteluja toimijuudesta ja identiteeteistä sairauskertomuksissa. Arduserin $(2014,24)$ tutkimuksessa positiointianalyysi tekee näkyväksi toimijuuden eroja ja kyseenalaistaa sairauskertomusten voimaannuttavan merkityksen.

Bodil Hansen Blix, Torunn Hamran ja Hans Ketill Normann (2015) ovat tarkastelleet kahden etniseen vähemmistöön kuuluvan ikääntyvän saamelaisnaisen kokemuksia menetetyistä koulutusmahdollisuuksis- 
ta. Tutkijat osoittavat, kuinka narratiivinen positiointi rakentaa naisten toimijuutta kertomuksen altavastaajan positiosta kerronnan tilanteessa minuutta määritteleväksi toimijaksi (emt., 175).

De Fina (2013) on hyödyntänyt narratiivista positiointia analysoidessaan Yhdysvaltoihin laittomasti maahan tulleiden latinalaisamerikkalaisten naisten $(n=15)$ kokemuksia paikallisen kielen oppimisesta ja kielitaidon merkityksestä heidän elämässään. De Fina $(2013,58)$ keskittyy tutkimuksessaan erityisesti kolmannen tason positiointianalyysiin ja osoittaa, kuinka haastattelutilanteessa tuotetut identiteetit kietoutuvat laajempiin sosiaalisiin diskursseihin, joiden tunnistamisessa etnografinen lähestymistapa on keskeinen.

Anna Kinnunen (2013) on tarkastellut neljän henkilön mielisairaalapotilaita koskevia muistelukertomuksia kerronnan tilana ja sitä, miten haastateltavat kertovat aiheesta, joka kytkeytyy mahdolliseen toiseuden tuottamiseen. Kinnusen $(2013,48)$ artikkelissa positiointi kerronnan tilassa nostaa esiin tutkijan ja kertojan kohtaamisen ainutlaatuisena hetkenä, jossa neuvotellaan mielisairaalapotilaita koskevista kulttuurisista käsityksistä ja soveliaasta tavasta kertoa heistä.

\section{TUTKIMUKSEN AINEISTO JA KERRONNALLINEN YMPÄRISTÖ}

Tässä artikkelissa hyödynnetään Heli Mutasen väitöstutkimuksen osatutkimukseen tuotettua aineistoa, joka koostuu 15 nuoren aikuisen haastatteluista. Lisäksi aineistona on kenttäjakson aikana tehtyjä muistiinpanoja ja työpajatoimintaa määrittäviä asiakirjoja, joiden avulla pyrittiin ymmärtämään tutkimuksen kerronnallista ympäristöä.

Haastateltavat rekrytoitiin eräältä itä-suomalaiselta työpajalta touko-kesäkuussa 2015. Jokaiselta työpajalla kyseisenä ajanjaksona olleelta noin 25 nuorelta aikuiselta kysyttiin osallistumishalukkuutta. Ensimmäiset haastattelut toteutuivat jo ensimmäisen kenttäviikon aikana ja viimeiset kesäkuun loppupuolella. Haastateltavista 9 oli naisia ja 6 miehiä. He olivat iältään 17-26 vuotiaita. He olivat haastatteluhetkellä olleet työpajalla yhdestä kuuteen kuukautta. Osa heistä oli ollut nuorten palvelujärjestelmän asiakkaina useaan otteeseen ennen työpajalle tuloa. Kaksi haastateltavaa oli suorittanut ammatillisen perustutkinnon ja viisi ylioppilastutkinnon. Kuudella oli takanaan keskeytyneitä ammatillisia perusopintoja ja kahdella keskeytyneet lukio-opinnot. Haastattelut tehtiin työpajan tiloissa ja ne kestivät 30 minuutista puoleentoista tuntiin.

Haastattelutilanteessa hyödynnettiin haastateltavien elämänviivapiirustuksia. Heitä oli pyydetty kuvaamaan elämänviivan muodossa heille tärkeitä asioita ja tapahtumia lapsuudesta aina haastatteluhetkeen. Elämänviivapiirustuksia käytettiin haastattelun virittäjänä, koska koehaastattelussa toteutettu avoimella kysymyksellä aloitettu haastattelu (Hyvärinen \& Löyttyniemi 2005, 192-193) osoittautui työpajan nuorille aikuisille haastavaksi.

Haastattelu jatkui teemahaastatteluna, jossa haastateltavia pyydettiin kertomaan koulukokemuksistaan, ammatinvalinnastaan, mahdollisista työkokemuksistaan ja kokemuksistaan nuorille suunnattujen aktivointitoimenpiteiden asiakkaana työpajalla. Muutamat haastattelut kehittyivät rikkaaksi kerronnaksi, kun taas suurin osa haastateltavista vastasi lyhyesti haastattelijan kysymyksiin. Haastattelut nauhoitettiin ja litteroitiin sanatarkasti. Yksi haastattelu litteroitiin pelkästään muistiinpanojen pohjalta. Myös päällekkäispuhunnat, huokaukset ja naurahdukset sisällytettiin litteraatioon. Litteroitua aineistoa kertyi yhteensä 150 sivua (riviväli 1). Haastateltaville tarjottiin mahdollisuus lukea litteroitu teksti. Seitsemän haastateltavista vastasi viestiin hyväksymällä litteroinnin.

Litteroituun aineistoon perehtyminen osoitti, että suurin osa haastattelupuheesta sisälsi lähinnä lyhyitä selontekoja, jotka vain paikoitellen sisälsivät esimerkiksi Labovin ja Waletzkyn (1967) klassisen tarinan rakennemallin osat: abstraktin, orientaation, toiminnan, arvioinnin, lopputuloksen ja koodan eli lopetuksen. Haastattelupuhe sisälsi pikemminkin vastauksia haastattelijan kysymyksiin, lyhyitä kuvauksia sekä menneistä tapahtumista että haastatteluhetkeä lähellä olevista tapahtumista ja myös tulevaisuuden toiveista ja mahdollisuuksista.

Tutkimuksessa toteutettiin narratiivista etnografiaa (Gubrium \& Holstein 2008), joka laajentaa tarkastelun ja analyysin kertomusten sisällön ja rakenteen lisäksi myös kerronnan käytänteisiin ja 
sosiaaliseen ympäristöön. Sosiaalisen ympäristön nähdään oikeuttavan ja uusintavan tietynlaisia tarinoita ja kerrontaa ja marginalisoivan tai haastavan toisia tarinoita, mikäli ne eivät sovi instituutioiden tavoitteisiin tai arvoihin. Tässä mielessä kerronnan konteksti on yhtä tärkeä kuin kertomusten sisältö. (Gubrium \& Holstein 2008, 261-262.)

Narratiivinen etnografia tarkoittaa tässä artikkelissa sekä työpajaa koskeviin asiakirjoihin että työpajanuorten kokemuksia valottaviin aiempiin tutkimuksiin perehtymistä. Toiseksi etnografialla viitataan pajalla tehtyyn systemaattiseen kuuntelemiseen ja osallistuvaan havainnointiin. (ks. De Fina 2013, 45.) Haastattelija osallistui työpajalla 3-4 päivänä viikossa kahden kuukauden ajan päivittäiseen työtoimintaan. Hän havainnoi erilaisia puhetapoja ja keskusteli nuorten ja valmentajien kanssa pyrkien tavoittamaan työpajakontekstin sosiaalisessa eli kerronnallisessa ympäristössä vaikuttavia erilaisia mallitarinoita. Näiden tarinoiden tavoittaminen auttoi ymmärtämään haastattelukerrontaa ympäröiviä ehtoja ja mahdollisuuksia (ks. Gubrium \& Holstein 2008, 262).

Tässä artikkelissa kerronnallinen ympäristö (Gubrium \& Holstein 2008) tarkoittaa ensinnäkin haastattelutilannetta. Toiseksi kerronnallisella ympäristöllä viitataan työpajaan, jossa koulutus- tai työpolulta poikenneet nuoret aikuiset ovat asiakkaina. Kolmanneksi, kerronnallinen ympäristö viittaa yhteiskunnan tasolla vaikuttaviin koulutukseen ja työhön liittyviin kulttuurisiin mallitarinoihin.

Työpajalla se, mitä nuoret kertovat, eivät kerro tai miten he päättävät kertoa, kietoutuu niihin tarinoihin, joissa he ovat osallisina työpajan kerronnallisessa ympäristössä. Työpajan mallitarinat kumpuavat työpajatoiminnan tavoitteista, jotka määritellään sekä lainsäädännössä että työpajatoimintaa koskevissa asiakirjoissa (Valtioneuvoston asetus julkisesta työvoimapalvelusta 1344/2002, 23\$; Ylipaavalniemi, Sariola, Marniemi \& Pekkala 2005, 9).

Yksi tällainen mallitarina on aktiivisen pajanuoren tarina, joka viittaa siihen toimeliaisuuteen, jota nuoren aikuisen on pajalla osoitettava koulutus- tai työpaikkoja hakiessaan. Toisaalta, syrjäytymispuheesta kumpuava tarinamalli kategorisoi pajanuoret aktivointitoimenpiteiden kohteeksi ja marginaalissa oleviksi toisiksi.
Laajasti ymmärrettynä kerronnallinen ympäristö viittaa kaikkiin niihin sosiaalisiin ympäristöihin, joissa nuoret ovat osallisina esimerkiksi koulutusinstituutioissa, etsivässä nuorisotyössä ja TE-keskuksen ja sosiaalipalvelujen asiakkaina. Tätä kerronnalliseksi metaympäristöksi kutsumaamme tasoa edustaa sujuvia koulutus- ja työuravalintoja korostava koulutus- ja työvoimapoliittinen puhe. Se rakentaa kulttuurisesti jaettua ymmärrystä toivottavasta elämänkulusta eli kulttuurisia mallitarinoita ammatinvalinnasta, koulutusurista ja työntekijäkansalaisuudesta (ks. Isopahkala-Bouret, Lappalainen \& Lahelma 2012; myös Kuronen 2010).

Sekä työpajan kerronnallinen ympäristö että kulttuuriset mallitarinat ovat läsnä myös haastattelutilanteen kerronnallisessa ympäristössä. Kerronnallisen tutkimuksen tutkimushaastattelua voidaan pitää vuorovaikutuksena, jossa haastattelija ja haastateltava rakentavat kertomusta. Näin ollen haastattelijan kysymykset, kommentit ja suhtautuminen kertomukseen muovaavat haastateltavan odotuksia siitä, mikä on kontekstiin sopivaa ja haastattelijan toivomaa kerrontaa. Toisaalta myös haastateltavan kerronta vaikuttaa vastavuoroisesti haastattelijan esittämiin tarkentaviin kysymyksiin. (De Fina 2009.)

\section{HANNAN TOIMIJUUDEN JA IDENTITEETIN RAKENTUMINEN PIENISSÄ KERTOMUKSISSA}

Esitämme Hannan (pseudonyymi) kertomien pienten kertomusten avulla, kuinka narratiivista positiointianalyysia (Bamberg 1997, 2004a, 2004b) on sovellettu tarinan, kerronnan ja kulttuuristen mallitarinoiden tasoilla tässä aineistossa. Hannan kertomukset edustavat yhtä toimija- ja identiteettipositiota kuvaavaa tarinamallia, joka rakentui aineiston tarkassa lähiluvussa. Sen sijaan, että olisimme analysoineet yhtä pientä kertomusta kolmella eri analyysitasolla (vrt. Bamberg 2004b; Bamberg \& Georgakopoulou 2008), olemme valinneet lähempään tarkasteluun jokaisella analyysitasolla kaksi pientä kertomusta. Tämä mahdollistaa yhden pienen kertomuksen analysoimista hienosyisemmän toimijuuden ja identiteetin analyysin. Aluksi esittelemme tiivistelmän Hannan kerronnasta. 
Hanna on 21-vuotias nuori nainen. Hän kertoi haastattelun alussa kokemuksistaan ala-asteella (käytämme tekstissä haastateltavan käyttämiä käsitteitä) siitä, kuinka koulun aloitus jännitti, kuinka hän sai ystäviä ja kuinka hän joutui kiusatuksi ulkonäkönsä vuoksi. Hän kertoi myös retkistään äidin kanssa ja ajastaan mummolassa. Yläasteelle siirtyminen tuntui mukavalta, koska "oltiin vähän niin kuin isompia".

Seitsemännellä luokalla Hanna siirrettiin pienluokalle. Hänen mielipidettään kysyttiin päätöstä tehtäessä ja hän koki siirron hyväksi, koska "siinä silti saa niin ku paljon paremmin niin ku sitä tukkee". Hanna oli kertomansa mukaan koulussa melko hyvä oppilas. Erityisesti kieliopinnot kiinnostivat häntä. Tupakoinnin vuoksi pudonnut käytöksen numero kuitenkin nolotti. Yläasteen viimeisellä luokalla ammatinvalinnan kysymykset tuntuivat vaikeilta. Lapsuuden haaveet eläintenhoitajan työstä tai tanssijan urasta hautautuivat. Äiti kannusti siivousalalle tai hoitotyöhön. Oma mieli paloi kosmetologiksi tai kampaajaksi, mutta todistus ei niille aloille ollut riittävän hyvä. Opinto-ohjaaja ehdotti ravintolaalaa, johon Hanna lopulta vastustellen myöntyikin. Opinnot ammattiopistossa eivät sujuneet, ala ei kiinnostanut ja poissaolot lisääntyivät. Päätös keskeyttämisestä kypsyi.

Kun henkilökohtaisen elämän ongelmat lisääntyivät, Hanna tasapainoili itsenäisyyden ja yhteiskunnan tarjoaman tuen tarpeen välillä useita vuosia. Työvoimatoimiston ammatinvalintapsykologi kehotti Hannaa käymään työpajalla tutustumassa nuorille suunnattuun pajatoimintaan. Työpaja vaikutti houkuttelevalta paikalta ja Hanna aloitti työkokeilun helmikuun alussa 2015. Vaikka pajalle tulo aluksi jännitti, kertoi hän saaneensa rohkeutta toimia toisten ihmisten kanssa. Hanna kertoi, että pajalla hänet otettiin hyvin vastaan ja häntä neuvottiin kaikissa tehtävissä riittävän hyvin. Lisäksi hän on huomannut, että pajalla olevat nuoret ovat ihan tavallisia nuoria. Hyvää oloa siivitti myös osallistuminen pajalla tehtyyn taideprojektiin. Hanna on hakenut pajalla ollessa erilaisiin koulutuksiin, vaikka vieläkään hänellä ei ole varmuutta, mihin haluaisi tarttua. Tulevaisuus mietityttää, koska " pitäis jaksaa opiskella ja valmistua ammattiin" sekä etsiä töitä.

\section{TARINAMAAILMAN TASO}

Analyysin aluksi tarkasteltiin, keitä henkilöitä haastattelupuheeseen sisältyvissä pienissä kertomuksissa on ja kuinka haastateltava asemoi itsensä suhteessa muihin tarkoituksellisesti tai vähemmän tarkoituksellisesti eli millaiseen toimijapositioon hän asettuu. Toiseksi huomiota kiinnitettiin siihen, kuinka kertoja muuttaa toimijapositiotaan ja tarinalinjaa haastattelupuheen aikana. Analyysissa oltiin kiinnostuneita siitä, miten tarinan henkilöhahmot rakentuvat, kuka päähenkilöksi, kuka vastustajaksi, sivusta seurailijaksi tai kohteeksi (Bamberg 2004b, 333). Lisäksi analyysissa tarkasteltiin pieniin kertomuksiin sisältyviä tapahtumia eli sitä, mistä tarina kertoo ja mikä on merkityksellistä kertojalle (ks. Riessman 2002, 702). Ensimmäinen pieni kertomus sijoittuu haastattelupuheessa yläasteen ammatinvalinnasta kertovaan kohtaan haastattelun alkupuolelle.

\section{"Ihan sama"}

1) Haastattelija (H): Oliko sulla kotona mitä puhetta ammateista?

2) Hanna: Mh..no äiti on nyt sitä mieltä ollu aina, että jottain hoitotyötä (..) hoitotyön tyyppistä, siivous, tämmöstä, se ois ihan (.) niin ku omasta mielestäki, on ihan mukavaa.

3) H: Minkälaisia vaihtoehtoja ja ajatuksia sulla sit oli?

4) Hanna: No kosmetologi, parturi ja tulkki. Hyvä paras ystävä se (henkilön nimi) niin se kosmetologiks, kun siellä oli sitä matematiikkapuolta. Minä sitte tuota (..) $m h$ (...) opon kanssa oli sitte silleesti, että: "kyllä susta siihen kokkijuttuun", ni mie että no niin, no mennään sitte siihen haetaan ja sehän kuulosti ihan hyvältä. VÄḦ̈N oli sillon silleensä kyllä, että IHAN sama, mihin tässä mennään.

5) H: Oliko se siun oma päätös se kokkihomma vai tuntuko siusta että (..)?

6) Hanna: No tuntu sillon, että muut kehhuu sitä hurjan hyväks, et ihan sama, et mennän nyt vaikka sinne. 
KultTuUriset

\section{MALLITARINAT OVAT LÄSN $\ddot{A}$}

JO HANNAN POHTIESSA

AMMATINVALINTAANSA.

Ammatinvalinnasta kertovassa pienessä kertomuksessa henkilöhahmoina ovat Hanna itse, äiti, paras ystävä ja opinto-ohjaaja. Vaikka Hanna voidaan tulkita tarinan kertojaksi, hän ei asemoi itseään tarinan päähenkilöksi ja ammatinvalinnastaan päättäväksi toimijaksi. Hän hyväksyy tarinassa äidin tarjoaman vaihtoehdon ja mallitarinan naistapaisista ja perinteisesti työväenluokkaisista hoiva- ja siivousammateista (ks. esim. Käyhkö 2006) ja tulee näin ollen asemoiduksi altavastaajaksi ja ohjailtavaksi. Tosin Hanna arvioi (r. 4) omia mahdollisuuksiaan toiveammatteihinsa parhaan ystävänsä kyvykkyyden kautta ja asemoi itsensä matemaattisilta lahjoiltaan heikoksi (ks. Siivonen 2013). Kulttuuriset mallitarinat ovat läsnä jo Hannan pohtiessa ammatinvalintaansa. Huonolla "matikkapäällä" (ks. Siivonen 2013) ei voi tavoitella kaikkia saatavilla olevia ammatillisia vaihtoehtoja Tulkitsemme tämän niin, että asemoitumalla matemaattisilta kyvyiltään heikoksi hän puolustelee suostumistaan pakkovalintaan, jota hän kuvaa seuraavassa lauseessa (r. 4).

Tarinan tasolla Hanna esittää itsensä kohteena, joka ei ole vastuussa ammatinvalinnastaan eikä näin ollen väärää valintaa seuranneista tapahtumista. Kerronnan hetkellä aikuisempi Hanna (nykyinen minä) arvioi tarinan nuoren Hannan (entinen minä) toimintaa (ks. Komulainen 1998). Hän siirtyy aikuisen Hannan positioon selittämällä tarinan Hannan valintoja pakoiksi, joihin ei silloin voinut vaikuttaa (r. 6). Hannan haastattelussa ammatinvalintaa koskevaa puhetta oli runsaasti. Näin ollen tulkitsemme, että ammatinvalinta ja sen vaikeus ovat olleet Hannan elämässä merkityksellisiä kokemuksia (ks. Riessman 2002, 702), joissa hänen nuoruuden toimijapositionsa näyttää aktualisoituvan.

Toinen pieni kertomus, jossa Hanna puhuu mahdollisuuksistaan tehdä valintoja ja neuvottelee toimija-asemastaan sekä tarinan että kerronnan tasolla, syntyy hänen kertoessaan päätöksestään keskeyttää ammatillinen koulutus.

\section{"Minä päätän"}

7) H: Missä vaiheessa sie sitte rupesit aattelemmaan, että ei tää oo siun juttu tuo ala?

8) Hanna: Missäs mie olin, mie olin jossain tiiätkö sijotettuna vähän aikaa, en muista, missä mie olin, en ollut (paikan nimi) (..) vai oliko? No mut ku siellä kysytään, et "meinaatko nyt ihan" ja myöhän sillon lintsattiin, niin jos kerran voi, niin MINÄ PÄ̈̈T̈̈N tän koulun tähän.

9) H: No miltä se tuntu sitte se, kun sie olit keskeyttänyt sen koulun?

10) Hanna: No sillä hetkellä tuntu, että on aikuinen ihminen, ja voi tehä kaikkee muuta kuin käyvä kouluu.

Hanna neuvottelee uudesta tarinalinjasta ja uudesta kertojapositiosta. Tarinassa ovat mukana muut henkilöt, joita hän ei kerronnassaan tarkemmin määrittele. Tulkitsemme henkilöiden viittaavan niihin henkilöihin, joita Hanna on tavannut nuorille suunnattujen tukipalveluiden asiakkaana. Lisäksi tarinassa on vertaiseksi tulkittavissa oleva toinen nuori. Hanna häivyttää kerronnassaan mukana olevat muut ja asemoi itsensä sekä kertojaksi että päähenkilöksi, joka päättää elämänsä suunnasta keskeyttämällä ammatillisen koulutuksen. Yhteiskunnan näkökulmasta päätös ei ole rationaalinen, mutta Hannan kertomuksen näkökulmasta tulkitsemme päätöksen muutokseksi tarinalinjassa ja toimijapositiossa ja yritykseksi neuvotella kohti orastavaa toimijuutta. Se mikä yhteiskunnan näkökulmasta näyttäytyy epäonnistumisena, voi yksilön kannalta olla merkittävä siirtymä (ks. myös Komonen 2001, 225).

\section{KERRONNAN TASO}

Analyysin toisella tasolla tarkastelemme haastattelupuhetta haastattelutilanteessa syntyvänä vuorovaikutuksena. De Finan (2009, 240-241) mukaan 
haastattelutilanteessa on merkityksellistä se, miten haastateltava ymmärtää haastattelijan kysymykset ja se, millaisen kerronnallisen selonteon hän ymmärryksen perusteella tuottaa siinä tilanteessa. Lisäksi siitä, mitä haastateltava pitää kertomisen arvoisena ja miten tarkasti tai laajasti hän kertoo tai jättää kertomatta, neuvotellaan jatkuvasti haastateltavan ja haastattelijan välisessä vuorovaikutuksessa. Myös ne asiat, jotka kertoja päättää paljastaa siinä nimenomaisessa tilanteessa ja vuorovaikutuksessa muovaavat haastattelijan kysymyksiä ja haastattelussa syntyviä tarinalinjoja. (De Fina 2009, 240241,246 .) Näin ollen on mahdollista, että toisen haastattelijan kanssa tarinalinjat olisivat muotoutuneet toisenlaisiksi.

Hienosyinen analyysi haastattelijan ja haastateltavan vuorovaikutuksesta toi esille haastattelijan kysymyksistä useita tarinalinjoja, joihin haastateltava päätti asemoitua joko hyväksymällä tai torjumalla ne. Jo edellä esitetyssä tarinamaailman tason analyysissä, Hannan kerrottua vaikeuksistaan ammatillisessa koulutuksessa, haastattelijan kysymys (r. 7) antaa tilaa tarinalinjalle, jossa koulutusvalinta voisikin olla väärä: " ... sie sitte rupesit aattelemmaan, että ei tää oo siun juttu tuo ala?" Hanna tarttuu uuteen toimijuutta tukevaan tarinalinjaan (r. 8) ja asemoi itsensä päätösten tekijäksi ja oman elämänsä suunnasta vastaavaksi nuoreksi aikuiseksi tarinassaan "Minä päätän”.

Ennen seuraavaa, työpajalla olosta kertovaa katkelmaa haastateltava kertoi monista mutkikkaista elämäntapahtumista, joissa hänet useaan otteeseen asemoitiin yhteiskunnan tukitoimien kohteeksi. Haastattelun puolessa välissä haastattelija kutsuu Hannaa kertomaan kokemuksistaan työpajalla. Haastattelijan avoin kysymys (r. 11) johti eri haastatteluissa hyvin erilaisiin pieniin kertomuksiin (ks. De Fina 2009, 244). Hannan tulkinta kysymyksestä ja se, mitä hän seuraavassa pienessä kertomuksessa, "Me ollaan ihan normaaleja”, pitää kertomisen arvoisena juuri tässä tilanteessa, on kietoutunut hänen kokemuksiinsa muun muassa nuorten mielenterveyspalvelujen asiakkaana. Niistä Hanna on kertonut ennen tätä haastatteluteemaa.

\section{"Me ollaan ihan normaaleja"}

11) H: Miten sie oot tän sit kokenu täällä pajalla tän homman?

12) Hanna: Täällä on onnistunu nuo asiat ja on tarpeeks hyvin neuvottu ja sit on nähny, että jahah, et täällä on muitakkiin, vaikka kellään ei (puheesta ei saa selvää), eikä semmonen, missä on hulluja ja sekopäitä tai kaikki olis jotenki ihan töttöröö, vaan ihan normin olosia nuoria. Ei tää oo millään tavalla, että mie oon höperö tai urpo.

Kerronnan tason vuorovaikutuksen eli haastattelijan ja haastateltavan välillä käytävä merkitysneuvottelu (De Fina 2009) johtaa Hannaa kertomaan (r. 12) vastatarinan (Andrews 2004). Siinä hän asettuu vastustamaan sosiaalisesti jaettua mallitarinaa, joka marginalisoi työpajanuoria ja määrittää heitä toisiksi ja vähempiarvoisiksi. Hannan vastatarina tulee ymmärrettäväksi hänen kerronnan tilanteeseen tuomansa henkilöhistorian ja niiden positioiden kautta, joihin hänet on aiemmissa kerronnallisissa ympäristöissä asemoitu tai joihin hän on suostunut. Tulkitsemme Hannan muuttavan kertomaansa tarinalinjaa, jolloin muuttuu myös se positio, josta käsin hän puhuu (Davies \& Harré 1990). Hanna asemoi itsensä kertomuksen päh̆henkilönä päteväksi vastakohdaksi "hulluille", "urpoille" ja "höperöille" (vrt. Linde 1993). Hän legitimoi positionsa myös positioimalla muut pajalla olevat nuoret aikuiset "ihan normin olosiksi nuoriksi".

Haastattelu jatkuu haastattelijan kysymyksellä, joka suuntaa kerrontaa tulevaisuuteen. Hanna vastaa haastateltavan seuraavaan avoimeen kysymykseen (r. 13) jatkaen edellisessä katkelmassa alkanutta uutta tarinalinjaa (r. 14). Hän puhuu uudesta toimijapositiosta, joka rakentaa vahvistuvaa toimijuutta ja luo pohjaa uudenlaiselle identiteetille. Hän asemoi itsensä tarinan päähenkilöksi ensin hapuillen, mutta lopulta rohkeasti. Toimijuus ja vahvistuva identiteetti rakentuvat myönteisissä kokemuksissa työpajakontekstissa.

\section{"Tilaa omille jutuille"}

13) H: No, mitäs sitte kun tää työpajajakso päättyy? 
14) Hanna: Harmittaa, kun loppuu (..) oon viihtyny tosi hyvin ja..oon saanu tehä niitä omiakin juttuja ja sitte semmosia, mitä täältä tilataan ja muuta. On ollu tosi kiva. Ja sitte tääki (henkilön nimi) taideprojekti, niin siinä tuli semmonen eka vähän nolo juttu, et nyt tää mennee sinne ja tuossa lukkee vielä nimi. Mut sitte kun mentiin pystyttämään sitä, niin tuli semmonen rohkeus ja joku semmonen hyvä olo, että oma työ on tässä muitten töiden kanssa. Kylläpä oli uppee, että on saanu semmosta tehä.

Edellisiä (r. 13-14) pieniä kertomuksia olisi mahdollista analysoida myös tarinamaailman (analyysitaso 1) tasolla, mutta päädyimme tarkastelemaan niitä nimenomaan kerronnan tason analyysin esimerkkeinä (analyysitaso 2). Bamberg (1997) korostaakin, että vaikka tarinamaailma ja kerronta on tärkeä erottaa toisistaan analyyttisesti, kietoutuvat ne haastattelutilanteessa toisiinsa (ks. myös Pöysä 2009, 325). Molemmat katkelmat ovat haastattelun loppupuolelta. Haastattelijan ja haastateltavan välinen suhde oli kehittynyt haastattelun kuluessa luottamukselliseksi ja rennoksi neuvotteluksi mahdollisista ja tärkeistä tarinalinjoista. Näin ollen haastateltavan kerrontapuhe haastattelun loppupuolella sisälsi huomattavasti enemmän tapahtumien arviointia ja tunnelmia kuvaavia selontekoja kuin haastattelun alussa. Esimerkkinä olevissa katkelmissa Hanna oli valmis jakamaan kokemuksiaan haastattelijan kanssa (vrt. De Fina 2009, 246).

Haastattelun siirtyessä työhön ja tulevaisuuteen liittyviin teemoihin haastattelijan kysymykset tarjoavat työhön ja työntekijäkansalaisuuteen liittyviä tarinalinjoja (r. 15 ja r. 20): "Mikä sun mielestä sit vaikuttaa sun kohallas, että saat töitä?" Kysymys näyttää johdattelevan Hannan tarttumaan kulttuurisiin mallitarinoihin työn ja koulutuksen merkityksestä nuoren aikuisen elämässä. Myös haastattelija tarttuu vuorostaan Hannan kerrontaan (r. 18) kysymällä: "Eiks tää tunnu sit siun elämään sopivalta?" Kysymys tarjoaa vastatarinalinjaa, johon Hanna yhtältä asemoi itsensä ( $\mathrm{r}$. 20): "... oon vaan vielä semmonen haaveilija ja töllistelijä." Toisaalta kulttuurinen mallitarina asemoi hänet "vaan" haaveilijaksi ja töllistelijäksi.

Haastattelun keskittyessä nykyisyyteen kerronnan tason vuorovaikutuksessa tapahtuvat merkitys- neuvottelut tulivat vahvemmin esille kuin menneisyyden tapahtumien kerrontapuheessa. Tulkitsemme tämän siten, että menneisyyden kokemukset kerrotaan niistä toimijapositioista käsin, joihin kertoja itsensä asemoi (self-positioning) tai joihin hänet asemoitiin (being positioned) (Bamberg 2004a, 136). Haastattelutilanteen nykyisyyskertomuksissa hänen on näin ollen mahdollista asemoida itsensä toisenlaisiin tarinalinjoihin ja uusiin positioihin.

Toisaalta on syytä miettiä, esittääkö haastateltava asioita nykyhetkessä todella omasta näkökulmastaan vai pyrkiikö hän seurailemaan haastattelijan kysymyksissään tarjoamia tulkintoja. Usein myötäilevä puhe on lyhytsanaisempaa ja värittömämpää kuin omasta näkökulmastaan puhuvan haastateltavan puhe. (Pöysä 2010, 157.) Tässä haastattelussa Hanna asettuu varsin kiltisti ja aikuisesti seurailemaan haastattelijan kysymyksissä tarjoutuvia tarinalinjoja. Vastatarinoiksi tulkittavia tarinoita on vain muutamia, kuten "Me ollaan ihan normaaleja" ja seuraavan luvun ”Äiti päivystää ja Hanna haaveilee".

\section{KULTTUURISTEN HEGEMONISTEN}

\section{MALLITARINOIDEN TASO - "KUKA MINÄ OLEN?"}

Olemme pyrkineet tavoittamaan tässä aineistossa kulttuurisia mallitarinoita ensinnäkin lukemalla hienosyisesti koko haastatteluaineistoa ja etsimällä siitä toistuvia ilmauksia, puhetapoja ja toimija-asemia, jotka olemme tulkinneet merkityksellisiksi representaatioiksi (ks. De Fina 2013, 45-46). Toiseksi olemme pyrkineet perehtymään huolellisesti tutkimuksen sosiaaliseen kontekstiin eli kerronnalliseen ympäristöön (Gubrium \& Holstein 2008) ja siinä ilmeneviin puhetapoihin sekä myös työpajaa määrittäviin asiakirjoihin. Tarkastelemme seuraavassa Hannan haastattelun loppupuolen kerrontaa, joka sivusi työtä, työelämää ja tulevaisuuden suunnitelmia. Hanna asemoi itsensä haastattelupuheessaan suhteessa kolmeen tunnistettavaan yhteiskunnassamme vaikuttavaan kulttuuriseen mallitarinaan: protestanttisen työetiikan mallitarinaan, tarinaan koulutuksen välttämättömyydestä ja tarinaan yksilön vastuusta omasta elämästään.

Edellä mainitut mallitarinat esiintyvät useissa aineiston haastattelukertomuksissa, vaikka joissakin 
haastatteluissa viittauksia oli niukasti. Seuraavat esimerkit ovat muista aineiston haastattelukertomuksista haastattelujen loppupuolelta, jossa keskusteltiin työstä ja tulevaisuuden suunnitelmista:

"... että et oo mitään, jos sulla ei oo työpaikkaa" (Haastateltava 19),

"et pääsis silleen ite tienaamaan...niin ku työllä sen rahansa" (Haastateltava 7).

"Mh, noh tietysti koulutus pittää olla..." (Haastateltava 8).

"...niin sanotusti nykymaailmassa tarviit koulutuksen ynnä muuta, että pystyt elättää ittes" (Haastateltava 13).

..."että mitähän ne työkkärissäkin ajattelee tästä, kun ei onnistu" (Haastateltava 2).

Monessa haastattelussa ilmeni yksilöllisiä valintoja korostava mallitarina, johon kertojat tarttuivat siinäkin tilanteessa, että päätös näyttäytyi yhteiskunnan näkökulmasta ei-rationaalisena: "..tein aina suurimmaks osaks ite päätöksiä, niin ku oon pienestä asti tehnykki" (Haastateltava 16).

Niin Hannan haastattelussa (r. 4) kuin muussakin aineistossa esiintyi myös koulutettavuuteen - kenellä on oikeus ja millaiseen koulutukseen? (ks. Räty \& Snellman 1998; Siivonen 2013) liittyviä mallitarinoita ja niiden vastatarinoita (ks. Andrews 2004): "Hienoo, nyt siitä tulee joku lääkäri, kun se menee lukioon (sarkastinen hymähdys). Mut nyt kun on miettiny, niin ei yliopistoo meikäläiselle." (Haastateltava 5).

Seuraavassa pienessä kertomuksessa haastattelija kutsuu Hannaa kertomaan tulevaisuuden kuviteltua kertomusta työstä (ks. Georgakopoulou 2007, 38). Yllättäen protestanttisen työetiikan modernin ajan mallitarina tunkeutuu Hannan kertomukseen. Kertojana Hanna palaa kerronnassaan haastattelutilanteen alun toimijapositioon, josta käsin hän tarkastelee maailmaa: Hanna kertoo ja puhuu äidin suulla, kertoo sivusta eikä asetu päähenkilöksi (r. 16). Hän selittää pakot toisten asettamiksi (tässä tapauksessa äidin). Tulkitsemme tarinan niin, että mielipiteet ovat äidin mielipiteitä, raataminen on äidin työtä, mutta ei Hannan. Naurahdus (r. 18) avaa vastatarinan (vrt. Andrews 2004). Kertoja neuvottelee protestanttisen työetiikan tarinalinjasta eikä asetu "raatajan" positioon (r. 18 ja 20), jonka tulkitsemme viittaavan edellisen sukupolven kulttuuriseen mallitarinaan.

\section{"Äiti päivystää ja Hanna haaveilee”}

15) H: Jos sie mietit sit tulevaisuutta ja työtä, niin mitä se vois olla?

16) Hanna: Raskasta raatamista, niska limassa, pakko on raahautuu vaikka toinen käsi paketissa.

17) H: Mistä sulle tämä on tullu?

18) Hanna: Äiti on puhunu, että sinne on pakko mennä vaikka hampaat irvessä ainaki paikan piälle (naurua). Ja siitä on sitte silleensä, että äiti on semmonen aikamoinen päivystäjä ja kannustaja minun takana, että se on niin ku pakko saaha paperit ja niin se on ja miellään töitä ja tälleensä. Ja sitten (..) niin, no justiinsa silleensä.

19) H: Eiks tää tunnu sit siun elämään sopivalta?

20) Hanna: Mie oon vaan vielä semmonen haaveilija ja töllistelijä.

Keskusteltaessa tulevaisuudessa tapahtuvasta mahdollisesta työllistymisestä Hanna tarttuu seuraavassa katkelmassa toiseen kulttuuriseen mallitarinaan. Hän näyttää hieman vastustellen hyväksyvän kulttuurissamme vallalla olevan mallitarinan koulutuksen ja työn tärkeydestä ja yksilön vastuusta elämänsä rakentajana (r. 22). Tämän voi tulkita siten, että Hanna haluaa asemoida itsensä normatiiviseen mallitarinaan tavallisena nuorena aikuisena, eikä marginaaliin asemoituna pajanuorena tai koulutusta tai työtä vieroksuvana nuorena aikuisena (vrt. Tuohinen 2010).

Työpajakontekstiin sijoittuvassa haastattelutilanteessa on sopivaa sovittautua kulttuurissamme arvostettuun mallitarinaan eli tarinalinjaan, joka tuottaa nuorelle aikuiselle velvollisuuden suuntautua koulutus- ja työmarkkinoille ja oikeuden yhteiskunnan taloudelliseen tukeen (vrt. Davies \& Harré 
1990). Asettuminen kulttuurisesti hyväksyttyyn mallitarinaan ja identiteettipositioon ei suju kitkatta, koska itselle sopivaa mallitarinaa ei yhteiskunnassa näytä olevan tarjolla. Seuraavassa pienessä kertomuksessa haastattelupuhe siirtyy passiiviin ja jättää tulkintamme mukaan tarinan avoimeksi.

\section{"Pitää hiihtää eteenpäin vaan"}

21) H: Mikä sun mielestä sit vaikuttaa sun kohallas, että saat töitä?

22) Hanna: Et mie saan töitä? No se just, et pittää olla koulutus ja näyttöö, että on jaksanu ja on suorittanut ammatin..koulutuksen ja sitte se, että pittä̈...ei se tuu vaan naps naps, vaan pittää niinku..hiihtää etteen päin vaan niin ku koitta saaha se, niin (huokaus).

Myös analyysin kolmannella tasolla, jossa tarkastellaan, kuinka kertoja neuvottelee identiteeteistään suhteessa kulttuurisiin mallitarinoihin, kerronnan konteksti sekä haastattelutilanteena että laajasti ymmärrettynä sosiaalisena ympäristönä vaikuttaa siihen, mitä ja miten kerrotaan ja mitä kertomuksella halutaan saavuttaa (Gubrium \& Holstein 2008). Näin ollen identiteetit rakentuvat kertomuksissa ja kerronnan tilanteessa, yhdessä yhdenlaisiksi ja toisessa ehkä toisenlaisiksi. Kertomusten resursseina käytetyt mallitarinat ja neuvotellut identiteettipositiot voidaan ymmärtää keskeisiksi linkeiksi yksilöllisen ja sosiaalisen välillä (vrt. La Pointe 2010, 7).

Mitä voimme narratiivisen positiointianalyysin perusteella sanoa Hannan toimijuudesta ja identiteeteistä? Kertoessaan menneisyyden ammatinvalintaan liittyvistä kokemuksistaan Hanna asemoi itsensä kertomuksessa kohteeksi ja hakee näin ollen empatiaa ja ymmärrystä niille ratkaisuille, joita hän on myöhemmin elämässään tehnyt. Kertojan valitsema positio muuttuu hienoisesti hänen kertoessaan koulutuksen keskeyttämisestä. Uusi positio, johon hän varovasti pyrki itsensä asemoimaan, vahvistuu hänen kertoessaan myönteisistä kokemuksistaan työpajalla. Kun kerronta siirtyy tulevaisuuden suunnitelmiin, Hanna tukeutuu kulttuurisiin mallitarinoihin ja niiden tarjoamiin identiteettipositioihin. Vaikka kulttuuriset mallitarinat lävistävät Hannan kertomuksen, Hanna neuvottelee toimijana niiden tarjoamista identiteettipositioista. Hän yhtäältä tarttuu protestanttisen työeetoksen mallitarinaan, koulutukseen liittyvään mallitarinaan ja yksilön vastuuta korostavaan mallitarinaan. Toisaalta hän vastustaa (vrt. Andrews 2004) ja yrittää neuvotella toisenlaisesta, itselle sopivammasta tarinalinjasta, jota ei näytä yhteiskunnassa olevassa tarinavarannossa olevan tarjolla.

\section{POHDINTA}

Olemme soveltaneet artikkelissa narratiivista positiointianalyysia (Bamberg 1997, 2004a, 2004b) tutkittaessa toimijuuden ja identiteettien rakentumista kerronnallisena toimintana. Olemme pyrkineet aineistoesimerkeillä ja niiden tulkinnalla osoittamaan, että narratiivisen positiointianalyysin avulla on mahdollista tavoittaa monipuolisia ja syvälle luotaavia tulkintoja aineistosta, jossa kertomukset ovat pieniä tilanteisia ja vuorovaikutuksessa kehkeytyviä kertomuksia menneistä ja nykyisistä tapahtumista ja tulevaisuuteen suuntaavista toiveista ja haaveista (Bamberg \& Georgakopoulou 2008). Haastattelupuheen analyysi kontekstista irrotettuina kertomuksina ei toisi oikeutta niille nuorille, joiden kertomukset epäjohdonmukaisena, katkeilevana puheena voitaisiin tulkita tarinattomuudeksi (ks. Aaltonen 2002). Näin ollen suurin osa aineistosta olisi jäänyt käyttämättä, mikä olisi jättänyt pimentoon näiden marginaaliin asetettujen nuorten neuvottelut toimijuudestaan ja identiteeteistään.

Työttömien nuorten ja nuorten aikuisten kokemuksia luotaavassa viimeaikaisessa tutkimuksessa on analysoitu semioottisesti toimijuuden erilaisia ilmenemismuotoja (Lähteenmaa 2011), narratiivisella tutkimusotteella etsivän nuorisotyön piirissä olevien nuorten toimijuutta kulttuurisesti määrittyneenä täytymisenä (Juvonen 2014) ja syrjäytymisvaaraan asemoitujen nuorten toimijuutta elämänkulun kehyksessä (Kuronen 2010). Analyysi on kohdistunut kertomusten sisältöön, mutta myös kerronnan kontekstiin.

Tässä artikkelissa sovelletulla narratiivisella positiointianalyysilla ja narratiivisella etnografialla on mahdollista tavoittaa pienistä kertomuksista koostuvassa aineistossa toimijuuden tilanteinen hienosyinen 
rakentuminen sekä tarinamaailman että kerronnan tasolla. Etenkin kerronnan vuorovaikutuksen tason analyysi tuottaa aiempaa tutkimusta hienosyisemmän kuvan nuorten toimijuuden ja identiteettien rakentumisesta tekemällä näkyväksi kerronnan kontekstin monitasoisuuden.

Narratiivisen positiointianalyysin avulla voidaan yhdistää sekä haastattelutilanteessa rakentuvat pienet kertomukset että laajemmat kulttuuriset mallitarinat, joita tämän tutkimuksen nuoret aikuiset käyttivät kerronnan resursseina neuvotellessaan toimijuudestaan ja identiteeteistään. Analyysimalli nostaa tarkasteluun tutkimukseen osallistuvien nuorten aikuisten toimijuuden tilanteiset neuvottelut kulttuurisissa mallitarinoissa tarjoutuvista identiteettipositioista. Kulttuuriset mallitarinat, kuten tämän aineiston tarinat koulutettavuudesta, työetiikasta, koulutuksen merkityksestä yksilölle ja yksilön vastuusta elämänsä muotoilijana, eivät näin ollen pelkästään märitä yksilön identiteettejä. Tarkka, sekä positiointianalyysia että narratiivista etnografiaa hyödyntävä lähiluku paljastaa, kuinka haastateltavat tuottavat, hyväksyvät, vastustavat ja muokkaavat positioita. Lisäksi he kertovat toisin eli muotoilevat identiteettipositioita uudella heille merkityksellisellä tavalla ja rakentavat siten ymmärrystä itsestään.

Vaikka kolme eri analyysitasoa tuottaa monikerroksisen tulkinnan toimijuuden ja identiteettien rakentumisesta, on kolmen eri tason yhteys toisiinsa jossain määrin vaikeasti hahmotettavissa. Bamberg (2004b) esittää, että tarinamaailman (taso 1) ja kerronnan (taso 2) tasot ovat toisiinsa kietoutuneita. Analyysissa tasojen linkittyminen on hyvä ymmärtää ja kysyä, miksi haastateltava kertoo tietyn tarinan tietyssä tilanteessa ja mitä hän haluaa kerronnallaan saavuttaa. Myös analyysin kolmannen tason kulttuuristen mallitarinoiden linkittäminen suoraviivaisesti kerronnan mikrokontekstiin on herättänyt kritiikkiä, koska mallitarinat voivat jäädä tutkijan arvauksiksi siitä, mitä sosiaalisen maailman representaatiota haastateltava käyttää kertomuksissaan (Benwell \& Stokoe 2006, 158-159).

Tässä artikkelissa sosiaalisen maailman representaatioiden havaitsemista tukee narratiivinen etnografia, kenttäjakso työpajalla, perehtymien aiempaan tutkimuskirjallisuuteen ja nuorten syrjäytymistä ehkäiseviä toimenpiteitä määrittäviin asiakirjoihin.
Lisäksi analyysissa on etsitty koko aineistossa esiintyviä yhteneviä puhetapoja, joiden olemme tulkinneet viittaavan kulttuurisiin mallitarinoihin (vrt. De Fina 2013, 45, 54-55).

Olemme esimerkeissämme puhuneet yhdestä Hannasta, mutta tilastojen valossa koulutuspoluilla kompastelevia, ammatilliseen tutkintoon johtavan koulutuksen keskeyttäviä nuoria aikuisia on edelleen 7,8 prosenttia opiskelijamäärästä, vaikka keskeyttäjien osuus onkin laskenut 2000-luvulla (Suomen virallinen tilasto 2012). Tämän artikkelin aineistoesimerkeissä ja analyysissa esiin tullut toimijuus voi vahvistua tai myös kadota pidemmällä aikavälillä nuoren aikuisen elämänkulussa. Näin ollen tarvitaankin pitkittäistutkimusta, jotta yhteiskunnan nuorille suunnatuissa tukitoimissa saatujen kokemusten merkityksiä nuoren toimijuuden ja identiteetin rakentumisessa voidaan analysoida pidemmällä aikavälillä. Sekä Hanna että muut tutkimukseen osallistujat on tarkoitus kutsua uusintahaastatteluun vuoden päästä ensimmäisestä haastattelusta.

Vaikka tässä artikkelissa pystyimme esittämään vain muutamia analysoituja esimerkkejä aineistossa olevista pienistä kertomuksista, esitämme, että positiointiteoria ja narratiivinen positiointi analyysimenetelmänä linkittävät kertomusten mikro- ja makrotason tavalla, joka tässä aineistossa tuo näkyväksi orastavat toimijuuden aihiot. Samalla se antaa tilaa yhteiskunnan näkökulmasta marginaaliin asetettujen nuorten aikuisten itsemäärittelylle.

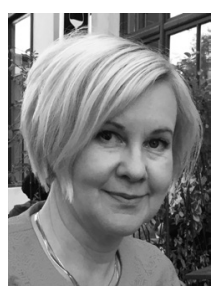

Heli Mutanen

$K M$, nuorempi tutkija/tohtorikoulutettava Itä-Suomen yliopisto

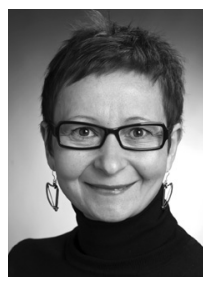

Päivi Siivonen

FT, yliopistotutkija

Itä-Suomen yliopisto 
Aaltonen, T. (2002). Sanatonko tarinaton?: afaatikon intersubjektiivinen maailma ja kertoen rakentuva identiteetti. Miina Sillanpään säätiön julkaisuja A: 5 . Helsinki: MSS.

Andrews, M. (2004). Opening to the original contributions. Counter-narratives and the power to oppose. Teoksessa M. Bamberg \& M. Andrews (toim.) Considering counter-narratives: narrating, resisting, making sense. Amsterdam: John Benjamins, 1-16.

Andrews, M., Day Sclater, S. \& Treacher, A. (toim.) (2004). Uses of narrative: Explorations in sociology, psychology and cultural studies. New Brunswick, NJ: Transaction Publishers.

Arduser, L. (2014). Agency in illness narratives. Narrative Inquiry 24(1), 1-27.

Atkinson, P. \& Delamont S. (2006). Rescuing narrative from qualitative research. Narrative Inquiry 16(1), 164-172.

Bamberg, M. (1997). Positioning Between Structure and Performance. Journal of Narrative and Life History 7(1-4), 335-342.

Bamberg, M. (2004a). Positioning with Davie Hogan. Stories, tellings, and identities. Teoksessa. C. Daiute \& C. Lightfoot (toim.) Narrative analysis: Studying the development of individuals in society. Thousand Oaks: Sage, 135-157.

Bamberg, M. (2004b). Form and Functions of 'Slut Bashing' in Male Identity Constructions in 15-YearOlds. Human Development 47(6), 331-353.

Bamberg, M. \& Georgakopoulou, A. (2008). Small stories as a new perspective in narrative and identity analysis. Text \& Talk 28(3), 377-396.

Benwell, B. \& Stokoe, E. (2006). Discourse and Identity. Edinburgh: Edinburgh University Press.

Blix, B. H., Hamran, T. \& Normann, H. K: (2015). Roads not taken: A narrative positioning analysis of older adults' stories about missed opportunities. Journal of Aging Studies 35, 169-177.

Davies, B. \& Harré, R. (1990). Positioning: The Discursive Production of Selves. Journal for the Theory of Social Behavior 20(1), 43-63.

De Fina, A. (2009). Narratives in interview - The case of accounts. For an interactional approach to narrative genres. Narrative Inquiry 19(2), 233-258.

De Fina, A. (2013). Positioning level 3. Connecting local identity displays to macro social processes. Narrative Inquiry 23(1), 40-61.

Deppermann, A. (2013). How to get a grip on identitiesin-interaction. (What) Does 'Positioning' offer more than 'Membership Categorization?' Evidence from a mock story. Narrative Inquiry 23(1), 62-88.
Edwards, A. \& Mackenzie, L. (2005). Steps towards participation: the social support of learning trajectories. International Journal of Lifelong Education 24(4), 287-302.

Emirbayer, M. \& Mische, A. (1998). What is agency? American Journal of Sociology 103(4), 962-1023.

Eteläpelto, A., Vähäsantanen, K., Hökkä, P. \& Paloniemi, S. (2014). Miten käsitteellistää ammatillista toimijuutta? Aikuiskasvatus 34(3), 202-215.

Evans, K. (2007). Concepts of bounded agency in education, work, and the personal lives of young adults. International Journal of Psychology 42(2), 85-93.

Georgakopoulou, A. (2007). Small stories, Interaction, and Identities. Amsterdam: John Benjamins.

Georgakopoulou, A. \& Goutsos, D. (2002). Revisiting discourse boundaries: The narrative and non-narrative modes. Text \& Talk 20(1), 63-82.

Gubrium, J. F. \& Holstein, J. A. (2008). Narrative ethnography. Teoksessa S. Nagy-Hesse-Biber \& P. Leavy (toim.) Handbook of Emergent Methods. New York: The Guilford Press, 241-265.

Hall, S. (1999). Identiteetti. Tampere: Vastapaino.

Harré, R. \& van Langenhove, L. (1999). Positioning theory. Moral context of intentional action. Malden, Mass: Blackwell.

Helsig, S. (2010). Big stories co-constructed. Incorporating micro-analytical interpretive procedures into biographic research. Narrative Inquiry 20(2), 274-295.

Hollway, W. (1984). Gender difference and the production of subjectivity. Teoksessa J. Henriques, W. Hollway, C. Urwin, C. Venn \& V. Walkerdine (toim.) Changing the Subject. Psychology, social regulation and subjectivity. London: Methuen, 227-263.

Hyvärinen, M. (2006). Towards a conceptual history of narrative. Teoksessa M. Hyvärinen, A. Korhonen \& J. Mykkänen (toim.), The travelling concept of narrative. Helsinki: Collegium, 20-41.

Hyvärinen, M., Hydén, L-C., Saarenheimo, M. \& Tamboukou, M. (2010). Beyond narrative coherence. An Introduction. Teoksessa M. Hyvärinen, L-C, Hydén, M. Saarenheimo \& M. Tamboukou (toim.) Beyond narrative coherence. Amsterdam: John Benjamins Publishing Company, 1-15.

Hyvärinen. M. \& Löyttyniemi, V. (2005). Kerronnallinen haastattelu. Teoksessa J. Ruusuvuori ja L. Tiittula (toim.) Haastattelu. Tutkimus, tilanteet ja vuorovaikutus. Tampere: Vastapaino, 189-222.

Hänninen, V. (1999). Sisäinen tarina, elämä ja muutos. Acta Universitatis Tamperensis 696. Tampere: Tampereen yliopisto. 
Isopahkala-Bouret, U., Lappalainen, S. \& Lahelma, E. (2012). Educating worker-citizens: visions and divisions in curriculum texts. Journal of Education and Work 27(1), 92-109.

Juvonen, T. (2014). Kulttuurisesti määrittynyt täytyminen osana nuorten aikuisten toimijuutta. Nuorisotutkimus 32(3), 3-16.

Kinnunen, A. (2013). Kohtaamisia kerronnan tilassa. Mielisairaalapotilaita koskevan muistelukerronnan rakentuminen. Elore 20(2), 33-53.

Komonen, K. (2001). Koulutusyhteiskunnan marginaalissa. Ammatillisen koulutuksen keskeyttäneiden nuorten yhteiskunnallinen osallisuus. Yhteiskuntatieteellisiä julkaisuja 47. Joensuu: Joensuun yliopisto.

Komulainen, K. (1998). Kotihiiriä ja ihmisiä: Retorinen minä naisten koulutusta koskevissa elämänkertomuksissa. Joensuu: Joensuun yliopisto.

Kuronen, I. (2010). Peruskoulusta elämänkouluun. Ammatillisesta koulutuksesta syrjäytymisvaarassa olevien nuorten aikuisten tarinoita peruskoulusuhteesta ja elämänkulusta peruskoulun jälkeen. Jyväskylän yliopisto. Koulutuksen tutkimuslaitos, Julkaisuja 26.

Käyhkö, M. (2006). Siivoojaksi oppimassa: Etnografinen tutkimus työläistytöistä puhdistuspalvelualan koulutuksessa. Joensuu: Joensuu yliopisto.

La Pointe, K. (2010). Narrating career, positioning identity: Career identity as narrative practice. Journal of Vocational Behavior 77(1), 1-9.

Labov, W. \& Waletzky J. (1967). Narrative Analysis: Oral Versions of Personal Experience. Teoksessa J. Helm (toim.) Essays in the Verbal and Visual Arts. Seattle: American Ethnological Society. Konferenssijulkaisu. http://www.ling.upenn.edu/ rnoyer/courses/103/ narrative.pdf (Luettu 5.10.2015.)

Linde, C. (1993). Life stories: The creation of coherence. New York: Oxford University Press.

Lähteenmaa, J. (2011). Nuoret työttömät ja yliviritetty toimijuus. Nuorisotutkimus 29(4), 47-60.

Opetus- ja kulttuuriministeriö. (2006). Nuorten työpajatoiminnan yleiset perusteet ja suositukset. http://www.minedu.fi/export/sites/default/OPM/ Nuoriso/nuorisotyoen_kohteet_ja_rahoitus/tyoepajat/ Liitteet/OPM_paatos_25102006.pdf. (Luettu 5.1.2015.)

Pöysä, J. (2009). Positiointiteoria ja positiointianalyysi - uusia näkökulmia narratiivisen toimijuuden tarkasteluun. Teoksessa S. Hägg, M. Lehtimäki \& L. Steinby (toim.) Näkökulmia kertomuksen tutkimukseen. Helsinki: Suomalaisen kirjallisuuden seura, 319-343.
Pöysä, J. (2010). Asemointinäkökulma haastattelujen kerronnallisuuden tarkastelussa. Teoksessa J. Ruusuvuori, P. Nikander \& M. Hyvärinen (toim.) Haastattelun analyysi. Tampere: Vastapaino, 153179.

Riessman, C. K. (2002). Analysis of personal narratives. Teoksessa J.F. Gubrium \& J.A. Holstein (toim.) Handbook of Interview Research: Context and Method. Thousand Oaks: Sage, 695-710.

Räty, H. \& Snellman, L. (1998). Social representations of educability. Social Psychology of Education 1(4), 359-373.

Siivonen, P. (2013). A bad head for maths? Constructions of educability and mathematics in adult students' narrative life histories. Scandinavian Journal of Educational Research 57(5), 507-525.

Suomen virallinen tilasto (SVT): Koulutuksen keskeyttäminen [verkkojulkaisu]. ISSN=1798-9280. 2012. Helsinki: Tilastokeskus [viitattu: 13.3.2016]. Saantitapa: http://www.stat.fi/til/kkesk/2012/ kkesk_2012_2014-03-20_tie_001_fi.html

Tuohinen, T. (2010). Nuorten 'työeetos' protestanttisesta etiikasta työyhteisön henkeen. Työpoliittinen aikakauskirja 4/2010. Työ- ja elinkeinoministeriö.

Valtioneuvoston asetus julkisesta työvoimapalvelusta 30.12.2002. http://www.edilex.fi/lainsaadanto/ aiempi/20021344_20051221 (Luettu 15.1.2015.)

Watson, C. (2007). Small stories, positioning analysis, and the doing of professional identities in learning to teach. Narrative Inquiry 17(2), 371-389.

Ylipaavalniemi, P., Sariola, L., Marniemi, J. \& Pekkala T. (2005). Sosiaalisen työllistämisen toimialan käsitteet. Helsinki: VATES-säätiö, Valtakunnallinen työpajayhdistys ry. http://www.vates.fi/media/ julkaisut_kirjat/sosiaalisen-tyollistamisen-toimialankasitteet-2005.pdf (Luettu 15.1.2015)

\section{LIITE 1: Litterointimerkit}

(..) kerronnassa esiintyvä lyhyt katkos

() äännähdykset: nauru, huokaus sekä epäselvät kohdat puheessa

KURSIIVILLA

muuta puhetta painokkaammin tai voimakkaammalla äänellä lausutut sanat tai tavut 